\title{
Making "Creative" Movement: Transformation of Urban Culture and Politics in Bandung, Indonesia
}

\author{
KIM Yujin \\ Graduate school of Asia and Africa Area Studies, Kyoto University; Yoshida-Honmachi, Sakyo-ku, Kyoto, Kyoto 606-8501, Japan. \\ E-mail: kim@asafas.kyoto-u.ac.jp
}

Received December 20, 2016; Accepted April 4, 2017

\begin{abstract}
This paper shows how Bandung city has emerged as a "Creative (kreatif) City" by examining the cultural practices by urban young people and the rise of Bandung mayor Ridwan Kamil. Westernized urban young people in Bandung have been historically developed into or conceptualized as "creative" (kreatif). The term kreatif doesn't have any specific definition but means anything new and different. Ridwan Kamil as an architect has shrewdly and successfully used the ambiguous concept of kreatif to become the Bandung mayor. Bandung has been the heart of popular culture in Indonesia since the 1970s. Many young people who enjoyed Western popular culture established the music magazine in the 70s and independent fashion outlets in the 90s. Creative industries have encompassed music and fashion industries since the mid-2000s. In 2008, Ridwan Kamil formed Bandung Creative City Forum in order to support such creative industries. As a result, youth cultural practices have been "creativised." Ridwan Kamil made an effort to realize Bandung as "Creative City" through several creative festivals. From the perspective of this historical socio-cultural context of the city, I argue that Bandung has two different characteristics, compared with other countries and cities, which adapted the creative industry policy: First, the city supported local products such as music and clothing by the bottom-up social movement, not by top-down government policy. Second, Bandung's creative movement boosted "brand localism," not the "brand nationalism."
\end{abstract}

Key words urban young people, creative city, creative industry, Bandung, Ridwan Kamil, branding

\section{Introduction}

The creative city has now become a globally recognized concept in rethinking the planning, development, and management of cities. The creative industries have been seen as an innovative sector of the creative city to become increasingly important to economic well-being. The industries of the twenty-first century will depend increasingly on the generation of knowledge through creativity and innovation (Landry 2000). Richard Florida (Florida 2002), in his first national bestseller, "The Rise of the Creative Class" (2002), examines creativity and its effects on economic development, and explains the rise of a new social class that he labels the creative class. According to him, they comprise scientists, engineers, architects, educators, writers, artists, and entertainers, who engage in creating new ideas, new technology. He contends that creativity promotes urban economic development.

This paper explores the historical background of the rise of the creative city of Bandung, Indonesia. Bandung joined the UNESCO Creative Cities Network in 2015. Since 2000s, several Indonesian researchers have pointed out that the city of Bandung has the potential to become a creative city in Asia (Aritenang 2013). However, they did not pay attention to how and why "creativity" became one of the new political resources of reformist leaders. In the case of Bandung, West Java, Indonesia, an architect has successfully used the concept of "creative" to gain the popularity of urban citizens in Bandung.

Several cultural studies researchers also mention creative industries. As Kong noted about creative industries, creativity itself is an "ambiguous" concept (Kong 2014). She raised seven issues in particular: (i) the difficulties in defining and scoping the creative industries; (ii) the challenges in measuring the economic benefits creative industries bring; (iii) the risk that creative industries neglect genuine creativity/culture; (iv) the utopianization of "creative labour"; (v) the risk of valorizing and promoting external expertise over local small- and medium-scale enterprises in the building of "creative industries"; (vi) the danger of overblown expectations for creative industries to serve innovation and the economy, as well as culture and social equity; and (vii) the fallacy that "creative cities" can be designed.

This paper largely accepts her argument, but she basically focused on the creative industries as government policy. In the case of Bandung, the city government has not played an important role in the creative industries 
policy. Many politicians such as Blair, a former Prime Minister of the UK (1997-2007), and Nakada, a former mayor of Yokohama, Japan (2002-2010), adopted the creative industry and the creative city as national or city government policy after they won the election. However, in Bandung, Ridwan Kamil as an architect as well as nonpolitical actor, or outsider ${ }^{1}$, has supported the creative industries as a kind of "social movement," not as a city government policy, since 2008.

The research aims to reveal two processes: (i) how Bandung as a heart of Indonesian popular culture, a basis for a creative city, has historically emerged since the colo-

Table 1. Chronological table

\begin{tabular}{|c|c|}
\hline Year & \\
\hline Late 19C-early 20C & Westernized city during Colonial era \\
\hline Late 1960s & Pro-Western open policy under the Suharto regime \\
\hline 1967 & Rock magazine, Aktuil, established \\
\hline $1970 s-80 s$ & Aktuil phenomenon \\
\hline Late 1980s & Change of youth lifestyles (e.g. Skateboarding) \\
\hline 1994 & Emergence of distro pioneers (e.g. Reverse) \\
\hline Late 1990s & Flowering indie scene \\
\hline 1997 & Asian Financial Crisis \\
\hline Early 2000s & Distro phenomenon \\
\hline \multirow[t]{2}{*}{2006} & Ridwan, winner of IYDEY award \\
\hline & Kickfest held \\
\hline Mid 2000s & $\begin{array}{l}\text { Rise of creative industries } \\
\text { Creative Kampung Movement }\end{array}$ \\
\hline 2007 & Birth of Bandung creative city \\
\hline 2008 & $\begin{array}{l}\text { Establishment of BCCF } \\
\text { Helarfest held }\end{array}$ \\
\hline 2012 & Helarfest 2012 \\
\hline 2013 & Ridwan won the mayoral election \\
\hline
\end{tabular}

Source: Author. nial era, the 1970s and 90s, and (ii) how "creativity" as an ambiguous discourse has become a resource for the political rise of Ridwan Kamil as an outsider who had no political party affiliation in the city since 2000s (Table 1). The final chapter shows the difference between Bandung and other cities from a comparative perspective.

To this end, this paper uses two main following methodologies: (i) participant observation in cultural events and music festivals, and (ii) interviews with urban young people, artists and musicians during several periods of field work in Bandung from 2015 to 2016.

\section{Bandung as a Westernized City}

The city of Bandung (Figure 1) is the capital of West Java Province in Indonesia and the country's third largest city by population, with around 2.5 million as of 2011. The city is located approximately $180 \mathrm{~km}$ south east of Jakarta and has cooler temperatures year-round than most other Indonesian cities because of its higher elevation. The city is also a center of education. At least 16 universities, three of which are state-owned such as Bandung Institute of Technology (ITB) (Figure 2), and 45 professional schools are scattered across the city. Bandung is also known for its wealth of clothing outlets such as "distros". As I discuss later in this paper, "distro" as an abbreviation of "distribution outlet" means small independent stores that sell a variety of products such as records, t-shirts, local and imported merchandise; usually run by the youth community such as Flashy, BLOODS, UNKL347, Riotic, and many other brands (Figure 2). Bandung as a fashion city attracts a huge number of visitors from surrounding cities (particularly from Jakarta), especially during weekends and holidays.

Bandung is a thriving cosmopolitan city. In the colonial era, the Dutch inhabitants of Bandung claimed the independent municipality, which was granted in 1906 .

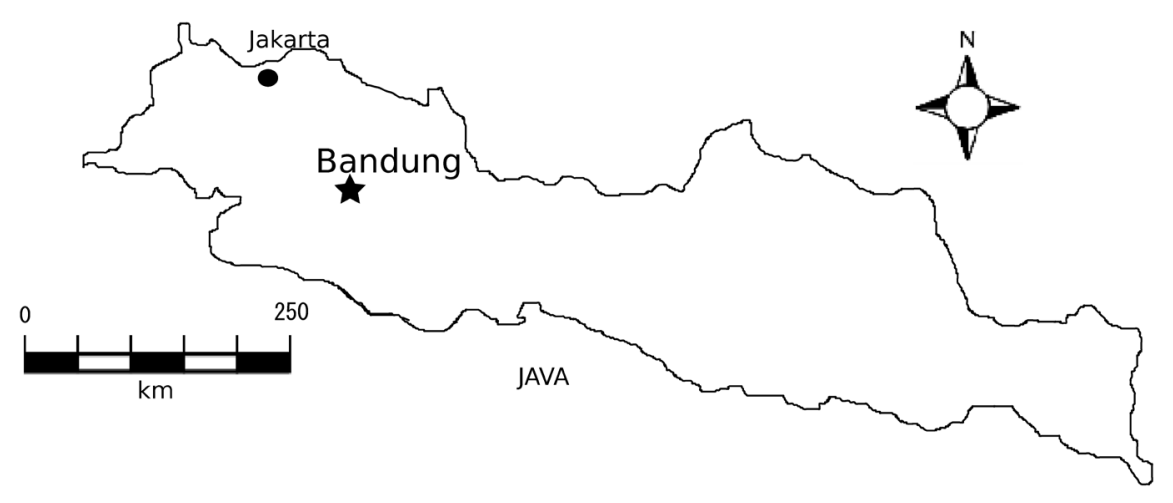

Figure 1. Figure 2 Map of the research site.

Source: Author. 


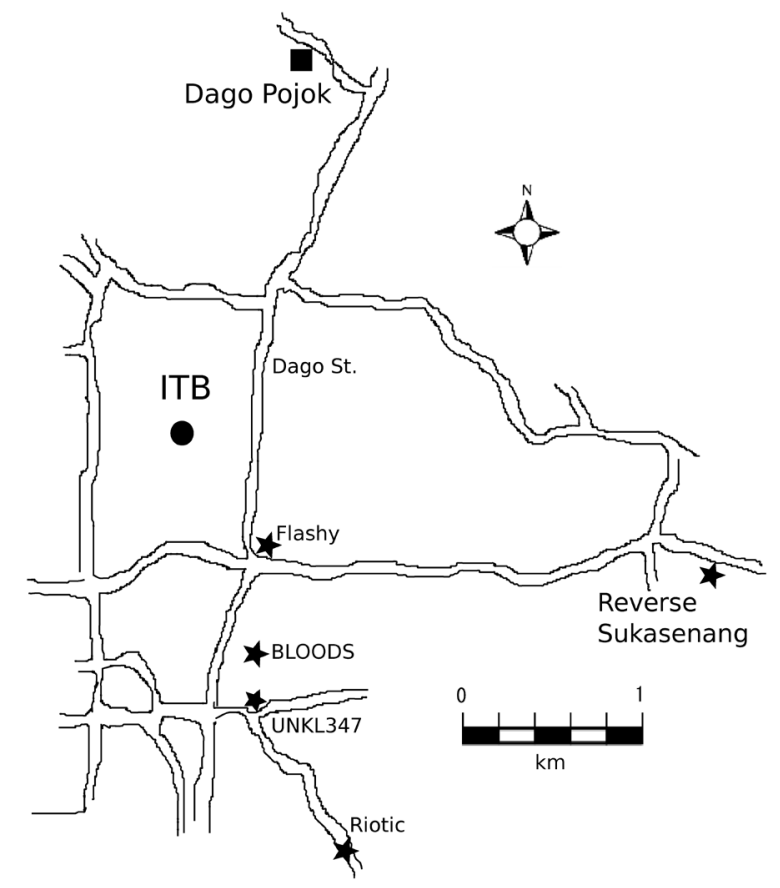

Figure 2. Map of ITB, distros, Sukasenang, Dago Pojok, Dago Street.

Source: Author.

We can still find various forms of European heritage. Today, in the cosmopolitan atmosphere, Bandung is called the "Parijs van Java". Bandung lays claim to being one of the liveliest and most varied cosmopolitan cities in the entire Indonesian archipelago. Since the Dutch colonial period, Bandung has had relatively more Europeans and students than any other regions ${ }^{2}$. The Europeans have had a significant influence on urban youth culture. Even to this day, many urban young people in Bandung have been influenced by the west (Western Europe and the United States) (Iskandar 2006). In the socio-cultural background of the city, Bandung became the home of a remarkably disproportionate number of Indonesian popular musicians (Wallach 2008).

\section{The Rise of Bandung as the Heart of Popular Culture-A 70s Trend}

Westernized urban young people have often become pioneers of new cultural practices in Indonesia since the 1970s. As those pioneers developed underground music in the 90s as described below, Bandung has come to be known as "the heart of underground music" (Baulch 2007). Additionally, Bandung is also the capital of fashion because it has many independent (indie) ${ }^{3}$ fashion outlets.

During the era of the authoritarian regime of president Suharto (1967-1998), young people were politically oppressed but they enjoyed Western popular culture. In
1967, three Westernized apolitical young people who lived in Bandung launched a local magazine, "Aktuil" in the city. Aktuil achieved unprecedented circulation and established a new category of magazine called "entertainment magazines for young people" as the first media that brought comprehensive information on Western popular culture to Indonesia (Takeshita 2011). This magazine won great popularity among urban young people in several major cities in Indonesia as it introduced Westernized rock music and lifestyle in the 1960s and 70s. From 1973-1974 the magazine even broke sales records by selling 126,000 copies more than Tempo, which was a dominant Indonesian weekly magazine by the end of 1972, and became a significant youth trendsetter (Takeshita 2011). Its rapid growth was supported by the pro-Western open cultural policy implemented by the Suharto administration. Nevertheless, Aktuil's peak achievement began slowly decreasing in 1977, and publication stopped in the 1980s after the editors stopped working because they were discontented with their salaries.

The Aktuil phenomenon showed that Bandung had become an epicentre of Indonesian popular culture. In other words, Bandung provided an arena for daily cultural practices of urban apolitical "ordinary" young people in the 70s. In Bandung, the 90s young generation also created a very similar phenomenon. Urban young people in the city developed an indie scene in the 90s (Sakrie 2015), as the city became the birthplace of the "distros" that carry fashion and indie music labels.

\section{The Birth of Independent Music and Fashion Scene-A 90s Trend}

The distro is a small independent store that sells a variety of products such as records, t-shirts, local and imported products, usually run by the youth community. Stores like shopping malls did not sell those products. Most importantly, the distro was born in Bandung and became popular all across the country in the mid-90s.

In 1994, three young people, Richard Mutter, Helvi, and Dxxxt, who lived in Bandung, started to build "Reverse" as a small recording music studio in the Sukasenang area (Figure 2) with the spirit of do it yourself $(\mathrm{DIY})^{4}$. Reverse only sold specific products to serve the enthusiastic fans of underground music and skateboarding in the city. This community was the first among a growing number of youth communities and subculture groups at the time. This small studio became one of the pioneers of distros to sell indie band merchandise including t-shirts, hooded jackets, accessories, CDs, cassette 


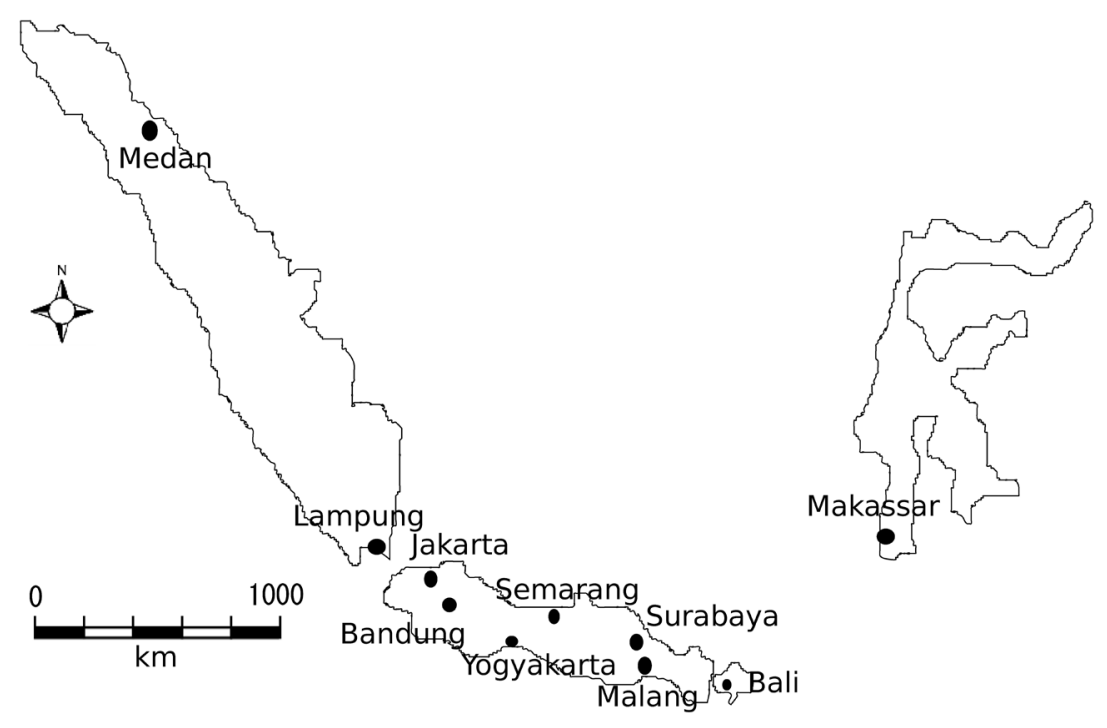

Figure 3. Map of the venues of Kickfest.

Source: Author.

tapes, and posters as well as other local and imported items. This pioneer distro paved the way for many future independent fashion outlets (Uttu 2006) and can be considered an important milestone of young community development in Bandung in the 90s.

Distros have rapidly expanded from the end of the 1990s to the 2000s. The number of distros in Bandung drastically increased from only seven in 1998 to over two hundred in 2006 in Bandung alone (Uttu 2006). Hot on the heels of the success of the pioneer distros, others began appearing throughout several major cities in Indonesia-in Jakarta, Jogjakarta, Malang, Semarang, Surabaya, Bali, Makassar, Medan and Lampung (Figure 3). While official statistical data is not available, it is roughly estimated that the total number of distros is at least around seven hundred throughout the country beyond Bandung in 2012 (Achwan 2013).

There are four main reasons for the distro phenomenon that are quite important because these factors are related to the rise of a new leader, Ridwan Kamil.

First, the lifestyle of young people gradually changed in the late 1980s. At that time, some young people enjoyed skateboarding in Bandung (Iskandar 2006). They liked to wear t-shirts, jeans, and sneakers, and distros supplied these "cool" items for young people. Furthermore, the concept of skateboard community became the seed of underground music communities such as punk, hardcore and metal groups that became popular in the 90s. Underground music participants have assimilated the imported underground ideologies of "Do It Yourself" (Wallach 2008). This discourse was a way of thinking that placed high importance on the individual initiative of forming counter-cultures (Iskandar 2006).
Second, the interdependence between local indie music bands and local indie fashion brands has greatly deepened. In general, the rise of a new music scene creates a new fashion trend. Especially in Bandung, the music industry is closely related to the fashion industry, as a music studio such as Reverse became a clothing store, distro. When local indie bands request a distro to design and sell these band $\mathrm{t}$-shirts, in return, band members wear distro-designed t-shirts during gigs (Uttu 2006). As a result, both of them gain popularity concurrently.

Third, the Asian Financial Crisis in 1997 urged the "localization" of production and merchandise (Iskandar 2006; Wallach 2008; Abwar 2011). In 1998, the value of the Indonesian rupiah had collapsed to 17,000 rupiah per US dollar, compared to just 2,400 rupiah per dollar in June 1997. The pioneer distros had sold international merchandise imported from overseas, but they could no longer depended solely on them from 1997 because it became difficult to obtain imported items due to the steep increase costs at a time of economic crisis. Therefore, they began selling merchandise of the local indie bands. Many urban young people in Indonesia imitated the style of the pioneer distros and began to build new distros with the DIY ethic (Luvaas 2012; Safäat and Muttaqien 2015). They started to make and sell their own products with a minimum investment in each hometown. This increasing tendency is indicative not only in Bandung but also in other cities like Jakarta, Jogjakarta, and Surabaya.

Finally and most importantly, the introduction of the creative industry in the mid-2000s encompassed a number of industries including music and fashion. As a result, youth cultural DIY practices have been "creativized". Ridwan Kamil contributed to this creative phenomenon 
as described below.

\section{The Rise of the Creative Industries}

It is now common to hear that people and media use the term "creative" (kreatif) in Indonesia, such as creative industry (industri kreatif), creative economy (ekonomi kreatif), creative city (kota kreatif), and so on ${ }^{5}$. The discourse of "creative" became a buzzword of Ridwan Kamil as we see below.

The UK government, the home of the industry, and Indonesian government define the creative industries as "those industries, which have their origin in individual creativity, skill, and talent and which have a potential for wealth and job creation through the generation and exploitation of intellectual property" (DCMS 2001; Kathleen 2015).

The creative industries policy has been on the rise since the mid-2000s in Indonesia. In 2005, the Indonesian government categorized the creative industries into 14 subsectors: architecture, design, fashion, film, video, and photography, crafts, computer and software, music, art, publishing and printing, advertising, interactive games, research and development, performing arts, television and radio. In 2011, the culinary industry, which entered as the 15th subsector, significantly boosted the share of creative industries in the national GDP. In early 2015,

Table 2. Subsectors of the creative industry in the UK and Indonesia

\begin{tabular}{|c|c|c|}
\hline & UK & Indonesia \\
\hline 1 & advertising & advertising \\
\hline 2 & architecture & architecture \\
\hline 3 & crafts & crafts \\
\hline 4 & music & music \\
\hline 5 & designer fashion & fashion \\
\hline 6 & performance arts & performance art \\
\hline 7 & publishing & publishing \\
\hline 8 & TV \& radio & TV \& radio \\
\hline 9 & design & visual communication design \\
\hline 10 & film \& video & film animation video \\
\hline 11 & Interactive leisure software & photography \\
\hline 12 & software \& computer service & interior design \\
\hline 13 & art \& antiques markets & product design \\
\hline 14 & & visual art \\
\hline 15 & & culinary (2011) \\
\hline 16 & & app \& game developer (2015) \\
\hline
\end{tabular}

Source: DCMS (2001), Kathleen (2015). digital application and game developing also became creative industries as the 16th subsector (Table 2).

The government has promised to support further growth of the industry. In 2008, Trade Minister Mari Elka Pangestu said, "The creative industries help drive the national economy." ${ }^{6}$ The current president Joko Widodo (2014-(2019)) also stated that technology and culture-based creative industries would be the future of the country. In a discussion with prominent creative economy businesspeople, he said, "I agree to open more investment opportunities for the industry. The government will also give full financial support for the Creative Economy Agency (Bekraf: Badan Ekonomi Kreatif) so its work will be fruitful for us." 7 A contribution from the creative industry accounted for 7.8 percent of the total gross domestic product (GDP) between 2010 and 2013, according to Central Statistics Agency (BPS: Badan Pusat Statistik) data ${ }^{8}$.

As Sato argued, the Indonesian government has yet to draw a blueprint of the policy despite giving some credit for the potential of the creative industries (Sato 2011). However, if we discuss the creative industries, we should consider not only the national government but also the local social movement because the creative industries, especially music, are urban type industries (Masubuchi 2010). Especially in Bandung, Ridwan Kamil as an architect has been paying attention to Bandung's potential creativity as a new driving force for urban development. As the Chamber of Commerce and Industry (KADIN) said, "Bandung has been known as the centre of the creativity such as design, fashion, architecture, film and video, radio, music, and technology," and "Bandung is known as a trendsetter of youth fashion such as distros."

Ridwan Kamil, popularly known as Kang Emil, was born in Bandung in 1971 and now is the young Mayor of Bandung City (2013-(2018)). Ridwan is one of the most popular leaders in Indonesia. He is "the king of SNS (Social Networking Service)," as we know he has a lot of followers ( 2 million in Twitter, 2.8 million in Facebook, and 5.6 million in Instagram as of March 23, 2017). He is the most popular candidate for the post of West Java governor $^{10}$.

Ridwan studied architecture at ITB from 1990 to 1995. He continued to study for a Master of Urban Design at the College of Environmental Design, University of California (UC), Berkeley, the US from 1999 to 2001. After graduating from UC, he started to work as an architect in several foreign countries. In 2004, with considerable experience as an architect, Ridwan founded the firm Urbane Indonesia with three partners in order to 
solve urban problems through city branding by boosting creative industry. "The Rise of the Creative Class", the book written by Richard Florida (Florida 2002) in 2002, inspired him to implement the ideas of "creativity" in his hometown ${ }^{11}$.

In 2006, architect Ridwan Kamil won the International Young Design Entrepreneur of the Year (IYDEY) award by the British Council, which is a British organization specializing in international cultural and educational opportunities and promoting the creative industry in Asia. Returning from his two-week visit to London, where he won the award, Ridwan Kamil brought home an unusual souvenir. Ridwan carried the research reports he found on how creative activity drives the economy of England's capital. "I saw a shift in economic activities in London, where communities are moved by strong ideas. The interesting thing was that economic activities that started from a powerful idea didn't always rely on big capital. Whoever was the most creative was the most successful," he said ${ }^{12}$. Ridwan noticed that the creative industry in Bandung is based on a lifestyle such as the distro and indie music (Ridwan 2015).

In 2007, the British Council appointed Bandung as the first creative city pilot project in Indonesia at the conference of the East Asia Creative City Forum in Yokohama (Cohen 2015). Receiving an official guarantee from the home of creative cities, he established the Bandung Creative City Forum (BCCF) with his friends in January in 2008. BCCF has been promoting the idea of the creative industry by linking art and culture to local economic development.

The BCCF is a community forum consisting of various creative industries' representatives such as clothing and fashion, music, and visual arts. The forum becomes a hub for creative communities (komunitas kreatif) (Aritenang 2013). The BCCF has three major aims: To encourage people to develop a creative spirit and discover their own potential for creative thinking; to motivate and make them realize that their creativity can add value to the economy; and to make Bandung a more creative and inspirational city.

\section{City Branding through Creative Festivals}

The BCCF has managed many creative projects. It also collaborates on one project with Kreative Independent Clothing Komunity (KICK). KICK, which is a business forum for entrepreneurs and owners of local clothing and distro, has held a creative movement festival called Kickfest (Figure 4) every year since $2006^{13}$. Kickfest has

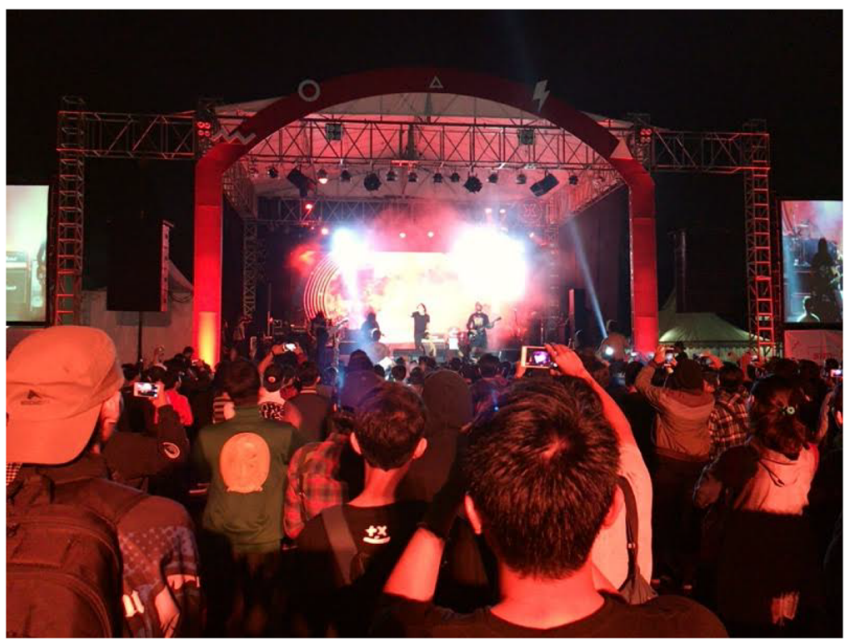

Figure 4. Kickfest 2016 in Bandung. Source: Author.

three important roles in the city branding.

First, Kickfest started to provide a better opportunity and venue year after year for indie fashion brands, indie music bands, and urban young people. The festival combined shopping experiences from around 100 distros and clothing companies with musical performances from promising local indie musicians. According to Kickfest 2013 general manager Ryan, "the festival had gained a reputation as one of the biggest signature events for clothing companies and clothes distribution in Indonesia. The best thing about Kickfest is that good products are available at cheaper prices. Every fashion item sold in the participating booths is $20-30$ percent lower than the normal price. Some Kickfest visitors, especially young people, came to the festival not only for shopping but also to enjoy musical performances by promising indie bands and big names on the Indonesian music scene. As Ridwan Kamil who attended Kickfest 2013 stated, "Kickfest represents the creativity of Bandung citizens and show a miniature version of Bandung." ${ }^{14}$

Second, Kickfest boosted "brand localism". Ryan said, "Kickfest is the epicenter of a creative movement for Indonesian youth, with fashion, music, community, and culinary foundations. This movement's goal is to strengthen our love for our own products." The festival was the embodiment of the "Support your Indonesian brand!" or "Support your local brand!" campaign. Kickfest has become one of the most successful events of the year. It also sends a clear message to young people that it is cool to wear Indonesian-made fashion items.

Third, Kickfest, as Indonesia's largest exposition for indie music and fashion, is now held outside Bandung as well, in cities such as Jakarta, Jogjakarta, Malang, and Makassar where the distros ran stores as of 2006, the 
Table 3. History of the venue(s) of Kickfest

\begin{tabular}{|l|l|}
\hline Year & \multicolumn{1}{|c|}{ Venue } \\
\hline 2006 & Bandung \\
\hline 2007 & Bandung \\
\hline 2008 & Bandung, Jogjakarta, Makassar \\
\hline 2009 & Bandung, Jogjakarta \\
\hline 2010 & Bandung, Malang \\
\hline 2011 & Bandung, Malang, Jogjakarta, Jakarta \\
\hline 2012 & Bandung, Malang \\
\hline 2013 & Bandung, Malang \\
\hline 2014 & Bandung, Malang \\
\hline 2015 & Bandung, Malang, Jogjakarta \\
\hline 2016 & Bandung, Malang \\
\hline
\end{tabular}

Source: Author.

first year of Kickfest (Figure 3, Table 3). Ryan said, "After seven years of conducting this annual festival, KICK aims to spread the creative movement in small cities in Indonesia." As the 70s Aktuil and the 90s distro phenomenon, the movement of Kickfest, originating from Bandung as the birthplace of Indonesian indie scene, became prevalent across the country in the 2000s.

\section{Creative Kampung Movement}

It is important that besides creative industry players among the middle-class Indonesian youth behind the indie scene, the urban poor have also been "creativized." The poor play an important role in the creative industry. The poor residents, who were evicted for urban development in Bandung, initiated the "creative kampung movement" (gerakan kampung kreatif) ${ }^{15}$ to reclaim their places to live ${ }^{16}$ (Ekomadyo et al. 2013; Rahmany and Djajadiningrat 2014).

One kampung that has been trying to respond to the urban renewal in Bandung is Kampung Dago Pojok. This kampung is located adjacent to the center of the urban renewal area, Dago Street corridor (Figure 2). Komunitas Taboo, a community concerned with child education, has been running their communal activities in this kampung since 2003. Komunitas Taboo implemented the idea to make Kampung Dago Pojok a significant part of the tourism economy in Bandung. This kampung had the rich tourism potential of the Sundanese ${ }^{17}$ traditional art and culture. Komunitas Taboo promoted local economic activities run by local inhabitants. The mural arts as their collaborative products in the street showed lively creativity of the kampung. According to Rahmat Jabaril, the founder of Komunitas Taboo, the village program brings a lot of innovations to people's activities, such as painting murals of the village ${ }^{18}$.

In this way, Kampung Dago Pojok has become synonymous with Creative Kampung (Kampung Kreatif) in Bandung as a result of the efforts made by three actors, or Komnitas Taboo, local inhabitants, and BCCF. The activities started from Dago Pojok, and perfectly matched the ideas that the BCCF had for their Kampung Kreatif program. Komunitas Taboo cooperated with the BCCF, which intended to develop art and tourism in Kampung Dago Pojok as its own program called Kampung Kreatif. This program aims to implement the idea of the creative city at the grassroots level. It encourages kampungs to find their own creativity utilizing their traditional culture. Themes include food, art, craft, music and dance. The goals of Kampung Kreatif are to set up cottage industries, develop tourism, improve the local environment, and create a sense of community and pride (Zijlstra 2014). The BCCF mobilized its members and using the network to gain more sponsors and greater exposure in the mass media. The BCCF provided its network, helped find sponsorship and drew up a roadmap, making sure the Dago Pojok community was on-board every step of the way. Through its involvement, the BCCF was able to bring the art and performing arts events in Kampung Dago Pojok to public attention. For example, the BCCF held a creative festival called Helarfest 2012: Festival Kampung Tamansari (20-22 September 2012) in order to expand the "creative kampung movement". As activists urge people to take part in a games festival, batik workshops, art exhibitions, free movie screenings, Sundanese pencak silat (Indonesian martial arts) demonstrations, Sundanese music performance, and a kampung guesthouse in Helarfest, the number of participants has gradually grown.

As a result, first, the term "creativity" has become visible among the urban poor. Second, Kampung Dago Pojok has become known as the pioneer of a Creative-Kampung Movement in Bandung. Finally, the term "creativity" has been shared among many more citizens of the city.

\section{Summary and Conclusion}

Many researchers tend to apply the creative city theory to a certain area or focus on the government policy. However they often overlook the historical socio-cultural context in the cities.

Since the colonial era, Bandung has been described as a thriving cosmopolitan city. Many young people in the 
city have been influenced by the west. Under the Suharto regime, they were politically oppressed but enjoyed Western popular culture as we saw in two examples of the 70s Aktuil and the 90s distro phenomenon. The creative kampung movement stretched the meaning of "creative" among the citizens. These cultural practices based on DIY ethics have been "creativised" due to the introduction of the creative industry policy in Indonesia. Ridwan Kamil, an architect and the chairman of BCCF, supported this industry in order to realize Bandung as a "Creative City" through several creative festivals such as Kickest and Helarfest.

From this perspective, it is apparent that the daily cultural practices of urban young people have been historically developed into or conceptualized as "kreatif." The creative industry and creative city play a role not only in urban cultural and economic policy but also in political slogans because the term "kreatif" itself is really ambiguous and could include anything new and different such as Aktuil, distro, and kampung. A new leader, Ridwan Kamil has shrewdly and successfully exploited the ambiguous concept of "kreatif" to gain the popularity of urban citizens in Bandung.

What is the difference between Bandung and other such cities? In the UK, Singapore, and Japan, political actors such as politicians and bureaucrats, adopted the creative industry or creative city as a national or city government top-down policy. On the other hand, in Bandung, urban young citizens such as musicians, owners of distros, various communities, and Ridwan, supported local products such as music and clothing by the bottom-up social activities. Indonesian government and city government only play a supporting role as facilitators of the policy.

In addition, the creative industry policy is often related to "brand nationalism". For example, the governments of the UK and Japan conduct "Cool Britannia" and "Cool Japan" campaign to promote these countries' soft power overseas. On the other hand, Bandung's creative movement boosted "brand localism." The rise of creative industries and creative cities urged urban young people to produce and consume local merchandise. Bandung has created a new and big trend ahead of other cities. As mentioned above, Aktuil, distro, and Kickfest, started from Bandung, and these cultural phenomena have extended to other cities. This geographical expansion implies that the "brand localism" will change to "brand nationalism" in the future. If it does, it is possible that a new Indonesian president who can skillfully use the term "kreatif" will be emerge beyond Bandung.

\section{Acknowledgements}

A summary of this paper was presented at the 11th Japan-Korea-China Joint Conference on Geography in September 2016 (New Otani Inn Sapporo).

\section{Notes}

1. Ridwan proudly said, "I'm not a political party member. I'm an architect." (Interview with him on August 29, 2016).

2. In Bandung as the academic city, the ratio of the population under the age of forty is around $60 \%$. See an example of Jogjakarta for your reference. Jogjakarta is well known as an academic city the same as Bandung. However, the ratio of young people (age $10-24$ ) in Bandung is $28.55 \%$ of the city's total population (BPS: Badan Pusat Statistik 2011), on the other hand, that of Jogjakarta is around $24 \%$ of the city's total population (CPPS UGM. July 15 , 2014: Perubahan Komposisi Penduduk, Jumlah Remaja DIY Naik Tiga Kali Lipat, TEMPO.CO. July 15, 2014: PBB Bentuk Klinik Reproduksi Pasien Muda di Yogya.). The ratio of young people in Bandung is higher than that of Jogjakarta.

3. Indie labels are independent music software companies. Indie musicians belong to indie record labels, not belonging to, working for or produced by large organizations or major labels.

4. DIY is the activity of making things by oneself at home, instead of paying somebody to do it.

5. See some headlines of Kompas, a most popular national newspaper in Indonesian; "Pemkot Bandung Prioritaskan Industri Kreatif" (Bandung City Government to Prioritize the Creative Industries) (January 5, 2010), "Era Ekonomi Kreatif" (A New Era for the Creative Economy) (November 3, 2011), "Pemerintah Kembangkan Kota Kreatif" (Government to Expand and Development Creative Cities) (July 10, 2011).

6. The Jakarta Post. March 17, 2008: Govt pumps export potential of the 'creativity industries'.

7. The Jakarta Post. August 5, 2015: 'Tech, culture-based industry the future of RI.'

8. The Jakarta Post. June 30, 2015: Govt pledges to help businesspeople in creative industry.

9. Bisnis Indonesia. October 10, 2015: Kadin: Bandung Pusat Industri Kreatif dan UKM Nasional.

10. Tribun Jabar. Maret 23, 2017: Ridwan Kamil dan Deddy Mizwar Tertinggi di Survei Indo Barometer.

11. Ridwan cited Florida's theory and wrote "Talent, Tolerant and Technology is key to Creative City" in his own book (Ridwan 2014: 336).

12. The Jakarta Post. December 19, 2008: M. Ridwan Kamil: Creativity at heart of success.

13. Jakarta Post Travel. October 23, 2013: 'Indonesian creative movement' attracts thousands in Bandung.

14. detikHOT. October 19, 2013: Ridwan Kamil Sebut Kickfest Jadi Representasi Kreativitas Warga Bandung.

15. Kampung means a village or a traditional urban high-density settlement.

16. Prasetyo, F. and Martin-Iverson, S. 2013. Art, Activism and the 'Creative Kampung': A Case Study from Dago Pojok, Bandung, Indonesia. Unpublished proceedings in Planning In The Era Of Uncertainty (Planink) International Conference on March 4-5, 2013 at University of Brawijaya, Malang.

17. The Sundanese are an ethnic group native to the western part of Java.

18. ANTARA News. August 3, 2015: Bandung conserves three cultural villages. 


\section{References}

Abwar, S. 2011. Bagaimana tren belanja distro bandung tahun depan? Tempo.co 9 Dec. https://m.tempo.co/read/ news/2011/12/09/110370847/bagaimana-tren-belanja-distrobandung-tahun-depan (last accessed 15 December 2015)

Achwan, R. 2013. Kelekatan kelembagaan: Industri distro fesyen di Bandung. Jurnal Sosiologi Masyarakat 18: 139-160. (IE)

Aritenang, A. 2013. The city of Bandung: Unfolding the process of a creative city. MPRA Paper No. 48629.

Baulch, E. 2007. Making scenes: Reggae, punk, and death metal in 1990s Bali. Durham: Duke University Press.

Cohen, D. 2015. Grounding mobile policies: Ad hoc networks and the creative city in Bandung, Indonesia. Singapore Journal of Tropical Geography 36: 23-37.

DCMS 2001. Creative Industries Mapping Documents 2001. London: Department for Culture, Media \& Sport.

Ekomadyo, A., Prasetyo, F. and Yuliar, S. 2013. Place construction and urban social transformation: An actor network theory analysis for Creative-Kampung Phenomena in Bandung. In Conference proceedings and program, Habitecno International Conference. ed. Habitecno International Conference, 230-239. Bandung: Institute of Technology Bandung.

Florida, R. 2002. The rise of the creative class: And how it's transforming work, leisure, community, and everyday life. New York: Basic Books.

Iskandar, G. 2006. Fuck you! we're from Bandung! http://bcfnma. commonroom.info/2003/fuck-you-were-from-bandung-mkii/ (last accessed 15 December 2015)

Kathleen, A. 2015. Boosting youth entrepreneurship in creative industries. Inside Indonesia 120: Apr-Jun 2015. http://www. insideindonesia.org/boosting-youth-entrepreneurship-increative-industries-2 (last accessed 15 December 2015)

Kong, L. 2014. From cultural industries to creative industries and back? Towards clarifying theory and rethinking policy. InterAsia Cultural Studies 15: 593-607.

Landry, C. 2000. The creative city: A toolkit for urban innovators.
London: Comedia.

Luvaas, B. 2012. DIY Style: Fashion, music and global digital cultures. London: Bloomsbury Academic.

Masubuchi, T. 2010. Yokubo no ongaku: "shumi" no sangyo-ka purosesu. Tokyo: Hosei University Press. (J)

Rahmany, R. and Djajadiningrat, S. T. 2014. Methodology of generating 'Creative Tourism Kampung' and stakeholders engagement analysis in Kampung Kreatif Dago Pojok project. Journal of Business and Management 3: 589-611.

Ridwan, K. 2014. \#Tetot: Aku, kamu, dan media sosial. Bandung: Sygma Creative Media Coup. (I)

Ridwan, K. 2015. Mengubah dunia bareng-bareng. Bandung: Mizan Publishing. (I)

Safa'at, B. and Muttaqien, S. 2015. Segera mulai distro milik sendiri. Jakarta: Grasindo. (I)

Sakrie, D. 2015. 100 tahun musik Indonesia. Jakarta: Gagas Media. (I)

Sato, Y. 2011. Keizai taikoku Indoneshia: 21 seiki no seicho joken. Tokyo: Chuko Shinsho. (J)

Takeshita, A. 2011. Popular culture in Indonesia during the new order: Reading process of constructing the "Newness" as reflected in entertainment magazines for young people. $\mathrm{Ph} . \mathrm{D}$. Dissertation, Osaka University. (JE)

Uttu 2006. Distro. Inside Indonesia 85: Jan-Mar. http://www. insideindonesia.org/distro (last accessed 15 December 2015)

Wallach, J. 2008. Modern noise, fluid genres: Popular music in Indonesia, 1997-2001. Madison: University of Wisconsin Press.

Zijlstra, S. 2014. Design action. Inside Indonesia 118: Oct-Dec 2014. http://www.insideindonesia.org/design-action (last accessed 15 December 2015)

(J) written in Japanese

(JE) written in Japanese with English abstract

(I) written in Indonesian

(IE) written in Indonesian with English abstract 